DOI: https://doi.org/10.47405/mjssh.v6i8.934

\begin{tabular}{|c|c|}
\hline 4.581 & Malaysian Journal of Social Sciences and Humanities (MJSSH) \\
\hline $\begin{array}{l}\text { Malaysian Journal of } \\
\text { Social cciences and }\end{array}$ & Volume 6, Issue 8, August 2021 \\
\hline (MJ-SSH) & e-ISSN : 2504-8562 \\
\hline & $\begin{array}{l}\text { Journal home page: } \\
\text { www.msocialsciences.com }\end{array}$ \\
\hline
\end{tabular}

\title{
Kajian Analisis Keperluan: Pembangunan Modul Pembelajaran Literasi Tenaga Pengintegrasian STEM Sekolah Rendah
}

\author{
Yusmail Jusup', Sabariah Sharif ${ }^{1}$ \\ 1Universiti Malaysia Sabah (UMS)
}

Correspondence: Yusmail Jusup (yussmile89@gmail.com)

\begin{abstract}
Abstrak
Kajian analisis keperluan dilaksanakan bertujuan untuk melihat isu dan permasalahan topik tenaga dan elektrik murid sekolah rendah di daerah Kota Kinabalu yang membawa kepada perlunya pembangunan modul literasi tenaga pengintegrasian STEM. Kajian ini dilaksanakan secara kualitatif dan kuantitatif. Kajian kualitatif yang menggunakan persampelan bertujuan melibatkan tiga orang guru dan empat orang murid menggunakan kaedah temu bual separa struktur manakala kajian kuantitatif melibatkan 100 orang murid responden menggunakan borang soal selidik keperluan murid. Hasil kajian kualitatif diperolehi berdasarkan kepada ciri keperluan yang dinyatakan oleh Morrison et. al iaitu i) keperluan sedia ada murid dan guru, dan ii) keperluan perasaan murid dan guru. Keperluan sedia ada murid dan guru dilihat melalui topik yang sukar diajar dan dipelajari, pengalaman pembelajaran murid, amalan pengajaran guru dan masalah yang dihadapi guru semasa mengajar topik tersebut. Keperluan perasaan iaitu keperluan untuk memperbaiki prestasi diri pula dilihat melalui keperluan yang diharapkan oleh murid semasa topik ini diajar dan keperluan guru dalam pengajaran topik ini. Kajian kuantitatif mempunyai 13 item soal selidik yang dianalisis secara deskriptif melalui skor peratus terdiri daripada lima kriteria iaitu tahap pengetahuan tenaga, amalan penggunaan tenaga, sikap terhadap tenaga, pengalaman pembelajaran dan keperluan strategi pembelajaran yang diharapkan. Dapatan daripada semua item dalam soal selidik menunjukkan peratus yang tinggi terhadap keperluan pembangunan modul untuk topik pembelajaran Tenaga dan Elektrik. Kesimpulannya, isu dan jurang permasalahan yang wujud membawa kepada perlunya pembangunan modul literasi tenaga dalam kalangan murid sekolah rendah di daerah ini agar literasi tenaga yang merangkumi aspek pengetahuan, sikap dan tingkah laku murid terhadap tenaga dapat ditingkatkan.
\end{abstract}

Kata kunci: analisis keperluan, pembangunan modul, literasi tenaga, pengintegrasian STEM

\section{Need Analysis Study: Development of Energy Literacy Learning Module with STEM Integration for Primary School}

\begin{abstract}
A need analysis study was conducted to identify the issues and problems in Energy and Electricity topic for primary school Kota Kinabalu district, which led to the need to develop an Energy literacy module with the Integration of Science, Technology, and Mathematics (STEM) element. This study was conducted by applying a qualitative and quantitative approach while utilizing the purposes sampling technique. The qualitative approach includes three teachers and four students performing a
\end{abstract}


semi-structured interview; meanwhile, the quantitative study was performed by gathering 100 students' respondents within the students' needs assessment questionnaire. The qualitative study results were obtained based on the characteristics of the needs stated by (Morrison et al.) namely i) the current needs of students and teachers and ii) the emotional needs of students and teachers. The current need of students and teachers can be seen through the difficulty of delivering and receiving the topic's content, students' capacity in learning, teachers' practice in teaching and finally, the issue faced by the teacher in delivering the topic itself. The need for feelings to improve self-performance is observed through the students' and teacher's needs and expectations while teaching and learning the topic. The quantitative research has 13 item questionnaires that descriptively analyzed through a percentage score consisting of five criteria: the level of knowledge in energy, energy consumption practices, attitudes towards energy, learning experiences, and expected learning strategy requirements. Findings from all items in the questionnaire showed a high percentage of developing a module focusing on the Energy and Electrical topic. In conclusion, the issues and dilemma gaps led to developing Energy Literacy modules among primary students in this district to improve students' knowledge, attitudes, and behaviors towards energy.

Keywords: need analysis, module development, energy literacy, STEM integration

\section{Pengenalan}

Kajian analisis keperluan merupakan fasa paling utama dan penting kerana akan menentukan bagaimana pembangunan bahan kandungan dalam modul akan dilaksanakan. Menurut Branch (2009) terdapat beberapa langkah yang terdapat dalam fasa analisis keperluan iaitu mengesahkan wujudnya jurang pencapaian, menentukan matlamat pengajaran, memastikan keperluan pengguna, mengenal pasti sumber yang diperlukan dalam proses pembangunan seterusnya dan menyediakan pelan pengurusan projek. Melalui fasa analisis ini, keperluan kumpulan sasaran iaitu murid dan guru sains dikenal pasti untuk dinilai dan dipertimbangkan (McKillip, 1987). Tujuannya supaya spesifikasi modul PdP Literasi Tenaga Integrasi STEM yang hendak dibangunkan adalah jelas (Casper, 2003) dan memenuhi matlamat serta keperluan kumpulan sasaran. Ia juga memastikan reka bentuk pembangunan modul ini adalah benar-benar satu keperluan (Smith \& Ragan, 2005) bagi menyelesai masalah pengajaran dan pembelajaran.

\section{Literasi Tenaga}

Masalah sumber bekalan tenaga yang semakin berkurang menjadi tumpuan di seluruh dunia. Bahan bakar fosil, cahaya matahari, sumber air dan tenaga nuklear merupakan antara sumber tenaga yang digunakan. Namun antara sumber yang diberi perhatian adalah sumber daripada tenaga boleh baharu seperti cahaya matahari, hidro, angin dan biomas yang digunakan secara meluas di beberapa buah negara. Sumber tenaga boleh baharu ini menjadi kepentingan dalam mengurangkan pembebasan gas rumah hijau yang memberi kesan kepada pemanasan global dan ancaman kepada pembangunan kelestarian (Harun \& Hoque, 2015). Menurut Liarakou, Gavrilakis dan Flouri (2009), bidang pendidikan merupakan pemangkin untuk memperkasakan murid dengan pengetahuan tenaga. Pembangunan dan pelaksanaan pendidikan tenaga sedia ada perlu dimantapkan lagi disamping memperbanyakkan program-program pendidikan berkaitan tenaga serta menjadikan aktiviti program tenaga sebagai sebahagian daripada aktiviti sekolah (DeWaters \& Powers, 2008). Pendidikan tenaga berperanan penting untuk membentuk sebuah masyarakat berilmu pengetahuan dan membangun bersama pembangunan mapan (Jenning, 2009).

Program pendidikan tenaga bertujuan untuk meningkatkan literasi tenaga murid menyasarkan bukan sahaja pengetahuan dan kemahiran kognitif tetapi juga sikap, nilai, kepercayaan, niat dan tindakan yang berkaitan dengan tenaga. Keberkesanan program pendidikan tenaga adalah untuk meningkatkan literasi tenaga murid dan harus dikaitkan dengan afektif dan tingkah laku serta kemahiran kognitif melalui pengetahuan yang baik (DeWaters et al., 2011). 
Satu kerangka pembangunan instrumen telah dibangunkan oleh DeWaters \& Powers (2011), untuk menentukan kriteria literasi tenaga. Penentuan kriteria-kriteria ini adalah berdasarkan rujukan kepada konsep sains (AAAS, 1989, 1993, NSTA, 1971), teknologi (Pearson \& Young, 2002) dan literasi alam sekitar (Harvey, 1977; Hungerford et al., 1980; Barrow \& Morrisey, 1989; Hofman, 1980; James, Robinson, \& Powell, 1994), standard pendidikan (NRC, 1996) dan bahan kurikulum, yang akhirnya menghasilkan definisi literasi tenaga yang luas dari segi ciri kognitif, afektif, dan tingkah laku (DeWaters \& Powers 2013). Secara umumnya, domain kognitif, afektif dan tingkah laku mempunyai satu set kriteria khusus atau objektif yang dapat diukur bersesuaian dengan setiap ciri seperti yang ditunjukkan dalam Rajah 1.

\section{Rajah 1 : Kerangka Pembangunan Literasi Tenaga}

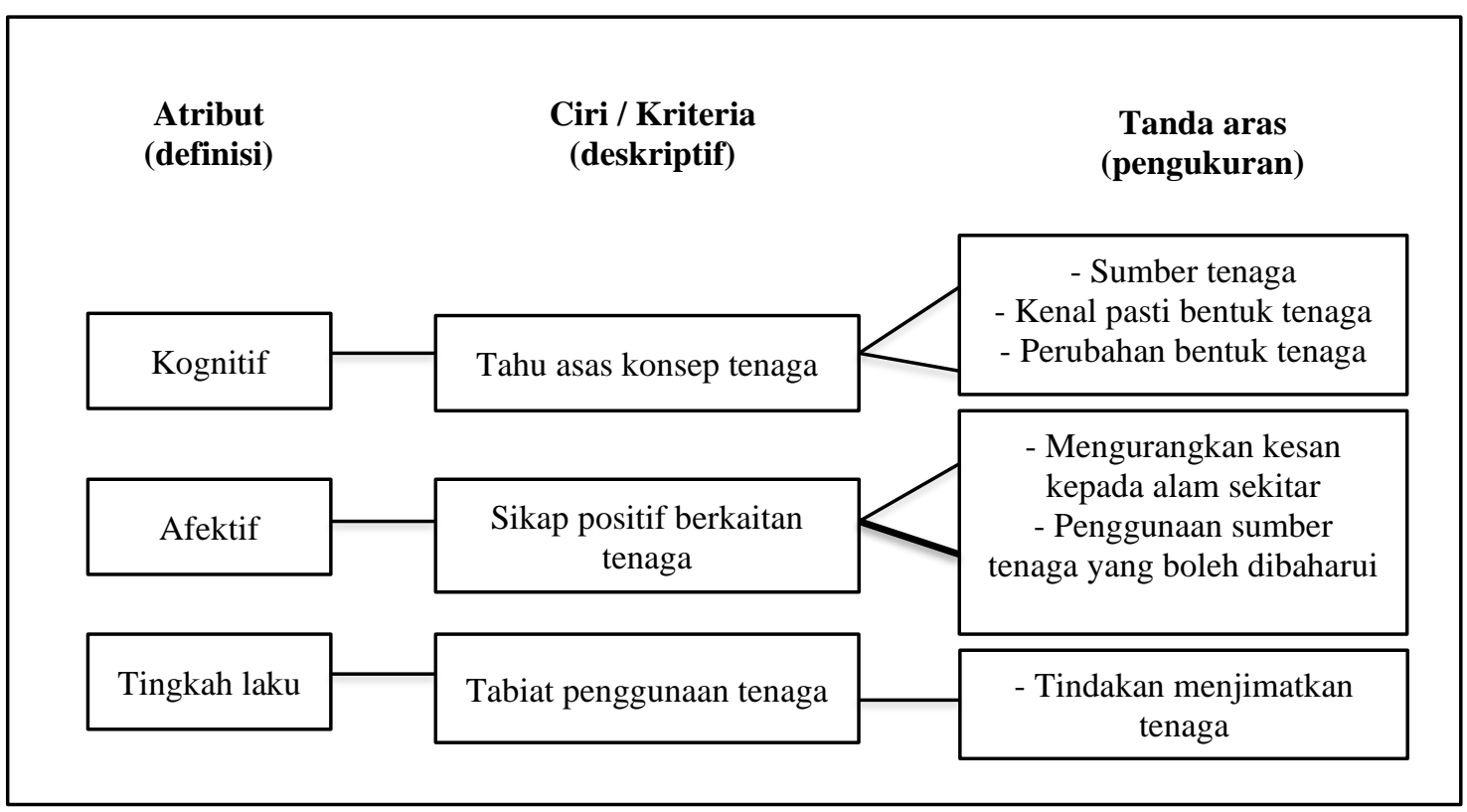

Sumber: DeWaters \& Powers (2011)

Berdasarkan kerangka pembangunan Literasi Tenaga, ciri-ciri afektif dan tingkah laku secara umum menggambarkan seseorang yang mengiktiraf kewujudan masalah tenaga global dan mempamerkan kesediaan untuk mengambil bahagian dalam penyelesaiannya (Salmon, 2000, St Clair, 2003, Wilke, 1995). Ciri-ciri kognitif termasuk kemahiran kognitif seperti analisis kritikal, penyelesaian masalah, dan nilai penjelasan, serta pengetahuan kandungan yang bersifat teknikal, atau formal, dan praktikal, atau tidak formal (Hofman, 1980; Solomon, 1992). Namun dalam modul yang hendak dibangunkan ini, kognitif murid adalah diukur berdasarkan kepada pencapaian murid untuk menguasai pengetahuan konsep-konsep topik Tenaga dan Elektrik seperti yang ditetapkan dalam DSKP edisi semakan (KPM 2017) manakala sikap dan tingkah laku murid terhadap tenaga adalah berdasarkan konsep definisi literasi tenaga yang telah dibangunkan oleh DeWaters dan Powers (2013).

\section{Pengintegrasian STEM}

Kelley dan Knowles (2016) mentakrifkan pengintegrasian pendidikan STEM sebagai suatu pendekatan untuk mengajar kandungan STEM yang terdiri daripada dua atau lebih domain STEM. Begitu juga dengan Moore et al. (2014) yang mentakrifkan pengintegrasian pendidikan STEM sebagai suatu usaha untuk menggabungkan beberapa atau kesemua disiplin sains, teknologi, kejuruteraan dan matematik ke dalam kelas atau unit pelajaran berdasarkan hubungan antara subjek dan masalah dunia sebenar. Wang et al. (2011) berpendapat, gabungan dua atau lebih subjek STEM dalam konteks integratif juga lebih dekat untuk dikenali sebagai pendekatan pengajaran antara disiplin (interdisciplinary) kerana ia bermula dengan masalah atau isu dunia sebenar yang merupakan pusat kepada kandungan dan kemahiran pelbagai disiplin subjek. 
Phang et al. (2014) mencadangkan pendekatan interdisiplin perlu digunakan dalam pendidikan STEM di Malaysia untuk mengurangkan cabaran pendidikan STEM di Malaysia. Pendekatan interdisiplin STEM adalah selari dengan konsep bersepadu kemahiran dan pengetahuan merentasi mata pelajaran seperti yang dicadangkan dalam Kurikulum Standard Sekolah Rendah (KSSR). Pendekatan interdisiplin STEM dikatakan paling senang dilakukan untuk peringkat sekolah rendah kerana guru yang sama mengajar beberapa mata pelajaran (Ostler, 2012). Reeve (2015) menyatakan guru-guru sekolah rendah dan menengah di negara-negara ASEAN perlu dilatih supaya dapat menggunakan praktis yang terbaik dalam setiap bidang subjek STEM. Penggunaan modul STEM merupakan salah satu cara yang berkesan untuk melatih guru melaksanakan pendekatan interdisiplin STEM (Asghar et al., 2012).

Lantz (2009) telah menetapkan lapan elemen yang diperlukan dalam pendidikan STEM, iaitu (i) berasaskan standard, (ii) pemahaman melalui reka bentuk, (iii) pembelajaran berasaskan inkuiri, (iv) pembelajaran berasaskan masalah, (v) PdP berasaskan pencapaian, (vi) pendekatan 5E, (vii) pengintegrasian teknologi digital dalam PdP, (viii) penilaian formatif dan sumatif dengan rubrik khas untuk tugasan dan bukan tugasan. Berdasarkan cadangan strategi-strategi PdP STEM oleh Lantz (2009), Wiggins dan McTighe (2005) dan Harland (2011); dalam modul ini pengkaji menyepadukan dua strategi STEM yang utama iaitu pendekatan pembelajaran berasaskan inkuiri dan proses reka bentuk kejuruteraan sebagai langkah aktiviti murid dalam modul Literasi Tenaga integrasi STEM.

\section{Metod Kajian}

\section{Reka bentuk dan Sampel Kajian}

Terdapat dua kaedah digunakan dalam kajian fasa ini iaitu temu bual separa berstruktur guru dan murid untuk data kualitatif, manakala borang soal selidik murid pula untuk data kuantitatif. Lokasi kajian untuk pengumpulan data kajian kualitatif dan kuantitatif melibatkan 2 buah sekolah rendah Kementerian Pendidikan Malaysia (KPM) di daerah Kota Kinabalu. Pemilihan lokasi kajian adalah mengambil kira kriteria peserta kajian yang dipilih secara bertujuan dan hampir menyamai sampel kajian sebenar. Pengkaji percaya dengan melaksanakan kajian analisis keperluan dengan mengambil kira kriteria sampel kajian sebenar dan lokasi yang sama, isu dan masalah yang sama turut berlaku di lokasi kajian sebenar nanti.

Bagi mendapatkan maklumat berkaitan keperluan pembangunan modul literasi tenaga STEM, pengumpulan data melibatkan dua kumpulan sasaran iaitu guru sains dan murid Tahun 6 yang mempunyai pengalaman mempelajari topik Tenaga dan Elektrik semasa berada di Tahun 5. Berdasarkan kepada tujuan kajian untuk membangunkan sebuah modul literasi tenaga STEM, maka penyelidikan ini bersifat konteks spesifik di mana peserta kajian yang dipilih adalah berdasarkan kepada permasalahan yang wujud dalam konteks yang dikaji (Saedah et al., 2013).

Peserta kajian yang dipilih adalah dari sekolah rendah, iaitu seramai tiga orang guru sains dan 100 orang murid Tahun 6 dari dua buah sekolah. Pemilihan peserta kajian guru adalah secara bertujuan berdasarkan kriteria guru yang terdiri Ketua Panitia dan guru mata pelajaran yang mengajar sains di sekolah rendah dan mempunyai kelayakan akademik dalam bidang sains dengan pengalaman mengajar murid Tahun 5 sekurang-kurangnya lapan tahun. Pemilihan sampel secara bertujuan bagi mendapatkan data kualitatif untuk memperoleh maklumat dan mengetahui perkembangan fenomena semasa yang berlaku di lokasi kajian (Creswell, 2008). Patton (2002) pula menyatakan bahawa bilangan sampel yang kecil membolehkan pengkaji dapat menyiasat sesuatu perkara itu dengan lebih mendalam.

Jadual 1: Latar Belakang Guru Analisis Keperluan

\begin{tabular}{ccc}
\hline Informan & Pengalaman Mengajar & Akademik Tertinggi \\
\hline Ketua Panitia Sains (KPS) & 15 Tahun & Sarjana muda \\
Guru Sains 1 (GS1) & 8 Tahun & Sarjana \\
Guru Sains 2 (GS2) & 10 Tahun & Sarjana muda \\
\hline
\end{tabular}




\section{Instrumen Kajian}

\section{Temu bual}

Bagi mendapatkan data kualitatif, pengkaji menyediakan protokol temu bual separa struktur. Kaedah temu bual separa struktur digunakan bertujuan untuk mendapatkan maklumat yang diperlukan oleh pengkaji secara bersemuka dengan informan dan ia lebih memfokuskan kepada tujuan kajian iaitu mengenal pasti isu masalah dan keperluan modul untuk dibangunkan (Ritchie \& Lewis, 2003). Temu bual yang dijalankan juga bertujuan mendapatkan maklumat pengajaran guru berkaitan isu dan masalah PdP topik yang berkaitan, strategi penyampaian dan aktiviti yang dijalankan dalam sesi PdP topik Tenaga dan Elektrik, pencapaian murid, dan aplikasi STEM dalam pengajaran. Maka maklumat yang diberikan oleh peserta kajian tersebut dapat digunakan untuk menentukan keperluan dalam membangunkan modul.

Selain itu, temu bual separa struktur turut dilaksanakan bersama murid. Tujuan adalah bagi mendapatkan data berkaitan keperluan, perasaan, dan pengalaman murid sebelum ini semasa pembelajaran topik Tenaga dan Elektrik semasa berada di Tahun 5. Selain itu temu bual bersama murid juga adalah berkaitan dengan masalah yang dihadapi semasa pembelajaran topik ini dan harapan mereka terhadap pendekatan yang digunakan oleh guru semasa pembelajaran topik ini. Kedua-dua instrumen protokol temu bual ini diberikan kepada dua orang pakar untuk kesahan.

\section{Soal Selidik}

Bagi data kuantitatif, borang soal selidik telah digunakan dalam kajian ini adaptasi daripada penyelidik lepas oleh DeWaters dan Powers, S. E. (2013), dimana ubahsuaian dilakukan berdasarkan keperluan kajian dan disahkan oleh dua orang pakar secara perbincangan. Soal selidik ini diberikan kepada murid dan bertujuan untuk mengumpul data mengenai tahap pengetahuan tenaga dan amalan penggunaan tenaga. Soal selidik ini juga melihat aspek sikap terhadap pembelajaran tenaga, pengalaman semasa pembelajaran iaitu kesukaran dan perasaan serta strategi pembelajaran yang mereka harapkan. Hasil analisis soal selidik ini sangat penting untuk melihat keperluan pembelajaran murid dan keperluan kepada pembangunan modul khususnya.

\section{Pengumpulan Data}

Sebelum proses pengumpulan data untuk kajian keperluan dilaksanakan, penyelidik terlebih dahulu mendapatkan kebenaran daripada Jabatan Pendidikan Negeri, Pejabat Pendidikan Daerah dan pihak pentadbiran dua buah sekolah rendah yang terlibat. Temu bual dilaksanakan secara individu ke atas tiga orang guru yang terdiri daripada satu orang ketua panitia (KPS) dan dua orang guru mata pelajaran Sains (GS 1\&2) yang mempunyai pengalaman lapan tahun ke atas dan mengajar tahap dua di sekolah. Selain itu, empat orang murid Tahun 6 yang dipilih sendiri oleh guru secara rawak turut ditemu bual dan untuk peringkat murid temu bual dilaksanakan secara berkelompok. Hal ini bagi menggalakkan murid berkongsi mengenai pengalaman mereka tanpa berasa kekok dan data yang diperolehi lebih bermakna dengan kajian. Soal selidik kemudian diedarkan kepada murid-murid Tahun Enam $(n=100)$ daripada dua buah sekolah. Murid Tahun Enam digunakan sebagai responden kajian dalam analisis keperluan kerana mereka mempunyai pengalaman mempelajari semua topik sains Tahun Lima sebelum ini. Masa yang diperuntukkan oleh murid untuk menjawab soal selidik adalah lebih kurang dalam tempoh 20 minit sahaja. Setelah data selesai dikumpulkan langkah seterusnya adalah proses menganalisis data keperluan.

\section{Hasil Kajian}

\section{Data Kualitatif}


DOI: https://doi.org/10.47405/mjssh.v6i8.934

Temu bual separa struktur yang dijalankan dalam fasa ini mengikut format tematik yang memfokuskan kepada analisis kualitatif bagi data temu bual (Catherine, 2015). Temu bual separa berstruktur yang digunakan ini memberi peluang kepada peserta kajian menyuarakan pendapat mengikut idea sendiri dan hasil data kualitatif yang diperolehi pula boleh dipercayai (Cohen, 2008).

Selepas temu bual dijalankan, analisis terhadap transkrip temu bual dilakukan untuk melihat makna dan maklum balas peserta kajian. Analisis tema bagi keseluruhan transkrip dilakukan dengan membuat perbandingan daripada kesemua peserta kajian guru dan murid. Ciri-ciri keperluan yang dikenal pasti dalam membangunkan modul literasi tenaga STEM adalah berdasarkan kepada beberapa ciri keperluan seperti yang dinyatakan oleh Morrison et al. (2007) iaitu, (i) keperluan sedia ada murid dan guru, (ii) keperluan perasaan iaitu keperluan yang dikehendaki untuk memperbaiki prestasi diri. Dapatan daripada proses menganalisis transkrip dibahagikan kepada dua tema iaitu keperluan sedia ada murid dan guru dan keperluan yang diminta murid dan guru.

\section{Tema i : Keperluan sedia ada murid dan guru}

Tema pertama adalah keperluan sedia ada yang dikenal pasti dalam kajian ini yang dilihat dari aspek topik sains yang dianggap sukar untuk dipelajari oleh murid dan diajar oleh guru. Pengalaman pembelajaran sains dan sikap oleh murid, amalan pengajaran dan masalah pengajaran sains yang dihadapi oleh guru turut termasuk dalam keperluan sedia ada murid dan guru. Keperluan sedia ada ini berguna bagi mengatasi kekurangan terhadap amalan PdP. Dapatan analisis temu bual terhadap masalah, amalan PdP yang biasa mereka laksanakan terhadap topik sains yang sukar dapat dijadikan sebagai panduan pentingnya untuk modul literasi tenaga STEM dibangunkan.

\section{Topik yang sukar}

Dapatan daripada temu bual terhadap topik sains Tahun Lima yang sukar dipelajari oleh murid serta diajar oleh guru adalah topik Tenaga dan Elektrik.

"Saya rasa tajuk Tenaga dan Elektrik paling susah untuk dipelajari. Sebab saya tidak faham cara cikgu mengajar" (M1)

"Susah sebab saya keliru belajar topik ini. Susah mau faham" (M2)

"Saya rasa belajar topik Tenaga dan Elektrik ini susah..." (M3)

"Saya tak pandai sangat dalam elektrik" (M4)

"Tajuk elektriklah antara topik yang sukar untuk diajar dan difahami kebanyakan murid...Selain itu topik Tenaga juga antara topik yang sukar" (KPS)

“...mereka tidak faham mengapa kita perlu jimatkan tenaga. Mereka tidak tahu kesan sekiranya tenaga dibazirkan dan kehilangan sumber tenaga suatu hari nanti”. (KPS)

“..salah satunya topik yang saya rasa mencabar adalah dalam tema sains fizikal, topik Tenaga dan Elektrik. Mencabar dan agak susah, contohnya untuk memberi kefahaman bentuk serta perubahan itu agak susah. Tenaga tidak boleh dilihat, jadi sukar untuk murid faham..." (GS1)

“...konsep dan kefahaman untuk tajuk Tenaga itu agak susah untuk mereka" (GS2) 


\section{Pengalaman pembelajaran murid}

Pengalaman pembelajaran sains yang dialami oleh murid khususnya dalam topik Tenaga dan Elektrik ini adalah lebih berpusatkan guru. Pembelajaran seumpama ini melibatkan pengalaman pembelajaran yang pasif oleh murid kerana murid hanya bergantung sepenuhnya kepada guru dalam memberikan maklumat. Manakala pembelajaran pengintegrasian pendidikan STEM pula memberikan peluang kepada murid untuk belajar secara aktif dengan memperoleh pengetahuan dan pelbagai kemahiran. Walau bagaimanapun, hasil temu bual bersama murid mendapati murid tiada pengalaman dalam pengintegrasian pembelajaran STEM di dalam kelas.

"Dia terangkan tentang tenaga dan bagi latihan" (M2)

"Cikgu terangkan. Lepas tu cikgu bagi soalan lepas tu kitaorang kena buat nota sendiri" (M3)

"Cikgu akan ajar dengan cara menulis nota dan terangkan di dalam kelas" (M4)

"kami tak pernah melaksanakan aktiviti pemasangan litar elektrik". (M1)

"kami tak pernah menggunakan macam sel suria untuk membuat litar elektrik dan menghidupkan mentol". (M2)

\section{Sikap murid terhadap pembelajaran dan penjimatan tenaga}

Sikap merupakan suatu nilai kepercayaan yang akan mempengaruhi cara murid untuk bertindak balas atau mendorong tingkah laku dan penerimaan murid terhadap pembelajaran sains sama ada cenderung ke arah tingkah laku pembelajaran yang positif atau negatif (Kamisah, Zanaton \& Lilia, 2007). Dapatan temu bual daripada guru mendapati murid kurang berminat untuk mengikuti pembelajaran topik Tenaga dan Elektrik yang diajar. Selain itu sikap murid terhadap penjimatan dan penggunaan tenaga di sekolah juga dilihat masih cenderung ke arah negatif.

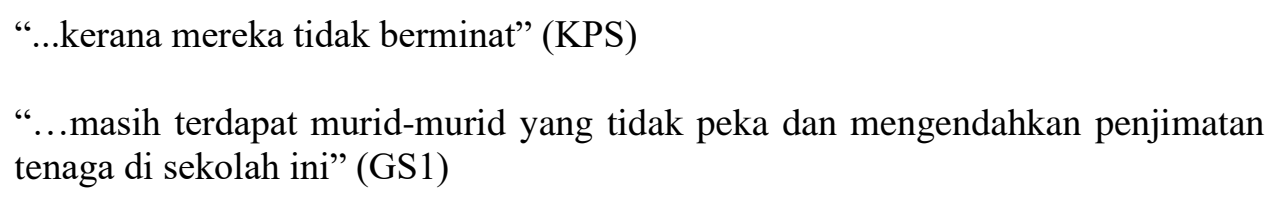

"Mereka membazirkan elektrik di situ. Kadang membuka pili air dan tidak menutup semula" (GS2)

\section{Amalan pengajaran guru}

Dapatan temu bual amalan pengajaran guru semasa mengajar topik ini dilihat lebih ke arah pengajaran konvensional dan berpusatkan guru. Selain itu guru juga sesekali melaksanakan aktiviti eksperimen mengikut keperluan dan kelengkapan bahan di bilik sains. Faktor kekangan bahan menyebabkan guru hanya menunjukkan aktiviti demonstrasi di hadapan kelas.

"Kalau kebetulan masa itu ada peralatan yang berkaitan tajuk pengajaran saya akan gunakan. Melaksanakan eksperimen, tunjuk cara dihadapan, kadang-kadang saya lebih kepada peta minda " (KPS)

"Saya lebih kepada pengajaran memberi penerangan dan sedikit eksperimen mengikut tajuk sekiranya perlu" (GS1)

“...pendekata kalau di sekolah ini kami masih berpusatkan guru. Guru masih memberi penerangan kepada murid. Kalau aktiviti eksperimen itu kami kurang sikit untuk tajuk ini.." (GS2) 


\section{Masalah/kekangan guru dalam pengajaran}

Masalah dalam pengajaran sains merupakan situasi atau keadaan yang mengehadkan pengajaran sains dengan berkesan di dalam kelas. Masalah tersebut mungkin mengekang usaha guru untuk membantu meningkatkan sikap murid serta pencapaian murid dalam sains khususnya untuk topik sains yang sukar dengan kurangnya pelaksanaan aktiviti pengajaran sains yang berkesan (Tenaw, 2014). Berdasarkan temu bual, terdapat beberapa masalah yang dihadapi oleh guru semasa mengajar topik Tenaga dan Elektrik ini antaranya ialah kekurangan kemudahan, sumber dan alat bantu mengajar, masa pengajaran sains yang singkat, tiada pendedahan dan panduan khas kepada penerapan pengintegrasian pengajaran STEM.
“...tapi kekangan daripada aspek kemudahan seperti peralatan dan bahan yang menyebabkan pelaksanaan tidak dapat dijayakan dengan sempurna. Kemudian dari segi persekitaran, bilik sains sendiri” (KPS)
“...masa sains hanya ada dua jam seminggu bersamaan dengan empat waktu sahaja. Selalu tidak mencukupi” (KPS)
"kami tiada pendedahan atau panduan cara mengajar mendedahkan STEM kepada murid" (KPS)
“...tiada panduan dan kid khas untuk pengajaran topik ini” (GS1)
"Bahan-bahan seperti sel suria, kincir angin, dinamo itu tiada disediakan. Cikgu- cikgu sentiasa bersedia untuk mengajar tetapi itulah kekangan dari kemudahan pengajaran". (GS2)

\section{Tema ii : Keperluan perasaan murid dan guru}

Keperluan perasaan merupakan keinginan seseorang individu untuk memperbaiki prestasi mereka sendiri atau yang dikehendaki oleh pihak lain. Ia merupakan suatu perasaan atau keinginan terhadap sesuatu keperluan yang bertukar menjadi kehendak (Morrison et al., 2007). Keperluan perasaan dalam kajian ini adalah kemahuan yang diperlukan oleh murid untuk menyukai dan meminati topik Tenaga dan Elektrik dari segi cara pengajaran guru. Manakala guru pula berkeinginan untuk meningkatkan kemahiran mengajar topik ini dengan lebih berkesan. Selain daripada keinginan terhadap keperluan dalam pengajaran topik ini, permintaan terhadap panduan pengintegrasian STEM melalui topik ini juga dilihat hasil temu bual yang dilaksanakan.

\section{Keperluan murid terhadap pengajaran guru}

Temu bual berkenaan keperluan murid terhadap pengajaran guru adalah berkenaan dengan kehendak yang mereka harapkan terhadap guru bagaimana topik Tenaga dan Elektrik ini disampaikan dalam PdP. Antara respons temu bual bersama murid menyatakan beberapa cadangan yang mereka sampaikan seperti aktiviti eksperimen, aktiviti berkumpulan melakukan projek sains dan menggunakan peralatan teknologi dan ICT dalam PdP.

"Saya nak cikgu terangkan guna LCD dan tunjukkan video" (M1)

"Saya suka secara eksperimen dan diterangkan" (M2)

"Saya pula nak buat projek dan kerja berkumpulan. Boleh bekerjasama dengan kawan-kawan" (M3)

"Saya pun suka eksperimen. Saya nak kita belajar buat dan cikgu akan tolong supaya lagi senang faham". (M4) 
Dapatan temu bual juga mendapati murid tidak pernah terlibat dalam aktiviti STEM dan menunjukkan minat serta keinginan yang kuat untuk melaksanakan aktiviti seumpama itu untuk tajuk Tenaga dan Elektrik.

"Saya pernah tengok orang buat dekat TV. Saya nak cuba buat contohnya kereta solar yang menggunakan suria". (M1)

"Kami tak pernah buat. Tapi kalau ada nak cuba buat sebab boleh belajar tentang sel suria. Boleh belajar macam mana gunakan sel suria dan memasang litar elektrik" (M2)

"Saya pulak saya nak cara belajar benda baru" (M4)

\section{Keperluan guru sains dalam pengajaran}

Keperluan guru sains juga dikenal pasti melalui temu bual ini dan secara keseluruhan guru menyatakan keperluan dan keinginan yang tinggi terhadap pengajaran sains khususnya topik Tenaga dan Elektrik dengan mengintegrasikan STEM dalam pengajaran untuk meningkatkan kemahiran mengajar topik ini dengan lebih berkesan.

“...kaedah ini lagi bagus, sebab boleh menggabungkan beberapa tajuk dalam satu pengajaran. Misalnya murid membuat projek”. (KPS)

"saya cadangkan supaya kandungan modul ini disediakan dalam dua bahagian iaitu pengajaran guru dan juga praktikal iaitu aktiviti murid. Tujuannya bagi menyesuaikan masa PdP Sains di dalam kelas yang mempunyai empat masa dalam satu minggu bersamaan 2 jam sahaja. Jadi satu jam pertama boleh diperuntukkan untuk pengajaran dan penerangan guru dan satu jam lagi untuk aktiviti murid". (KPS)

“...pihak tertentu dalam pendidikan perlu menyediakan panduan kepada guru khususnya untuk sekolah rendah subjek sains ini bagi kami memudahkan melaksanakan pembelajaran STEM ini. Sebab perkara ini masih baru bagi kebanyakan guru jadi aplikasinya didalam PdP masih ramai yang tidak faham" (GS1)

“...modul pengajaran STEM selain memudahkan guru, akan memberi peluang kepada murid untuk meneroka sendiri dan merangsang inkuiri mereka". (GS2)

\section{Data Kuantitatif}

Data yang diperoleh daripada soal selidik dianalisis secara statistik menggunakan perisian SPSS (Statistical Packages for Social Science). Data yang diperoleh dari hasil soal selidik keperluan murid dianalisis secara deskriptif melalui skor peratus, untuk menghuraikan secara menyeluruh data mengenai keperluan murid mengenai pembangunan modul pembelajaran modul ini. Analisis ini juga digunakan bagi mendapatkan jawapan responden kepada soal selidik dimana data dapat dianalisis dengan tepat serta menjimatkan masa. Hasil daripada analisis data ini digunakan bagi melihat dan mengenal pasti keutamaan keperluan dari perspektif murid.

Analisis keperluan murid yang dikenal pasti dalam kajian ini ditinjau dari beberapa kriteria iaitu tahap pengetahuan tenaga, amalan penggunaan tenaga, sikap terhadap pembelajaran tenaga, pengalaman pembelajaran tenaga dan keperluan strategi pembelajaran. Keputusan soal selidik dapatan analisis keperluan ini berguna bagi mengenal pasti masalah dan keperluan pembangunan modul literasi tenaga STEM sebagai intervensi untuk mengatasi kekurangan terhadap amalan PdP topik Tenaga dan Elektrik sebelum ini. Analisis soal selidik keperluan ini dianalisis menggunakan peratus dan hanya keputusan 
DOI: https://doi.org/10.47405/mjssh.v6i8.934

peratus tertinggi ditunjukkan bagi setiap item dalam kriteria yang ditetapkan. Jadual 2 menunjukkan keputusan kajian analisis soal selidik keperluan murid yang telah dibuat.

Jadual 2: Analisis Soal Selidik Keperluan Murid

\begin{tabular}{|c|c|c|c|}
\hline Kriteria & Item & Keputusan & Peratus \\
\hline \multirow{2}{*}{$\begin{array}{l}\text { Tahap } \\
\text { pengetahuan } \\
\text { tenaga }\end{array}$} & $\begin{array}{l}1 \text {. Berapa banyak yang anda rasa anda tahu } \\
\text { tentang tenaga? }\end{array}$ & $\begin{array}{l}\text { Sederhana (tahu serba } \\
\text { sedikit) }\end{array}$ & $55 \%$ \\
\hline & $\begin{array}{l}\text { 2. Manakah paling menyumbang kepada } \\
\text { pemahaman anda mengenai isu dan } \\
\text { masalah tenaga? }\end{array}$ & Sekolah & $31 \%$ \\
\hline \multirow{3}{*}{$\begin{array}{l}\text { Amalan } \\
\text { penggunaan } \\
\text { tenaga }\end{array}$} & $\begin{array}{l}\text { 3. Apabila menggunakan tenaga (elektrik) } \\
\text { bagaimana anda menggambarkan diri } \\
\text { anda? }\end{array}$ & $\begin{array}{l}\text { Pengguna tenaga } \\
\text { sederhana }\end{array}$ & $55 \%$ \\
\hline & $\begin{array}{l}\text { 4. Berapa kerapkah anda bercakap dengan } \\
\text { keluarga tentang cara menjimatkan tenaga } \\
\text { elektrik di rumah dan luar rumah? }\end{array}$ & Jarang-jarang & $45 \%$ \\
\hline & $\begin{array}{l}\text { 5. Adakah pembelajaran tajuk Tenaga dan } \\
\text { elektrik sekarang mampu untuk mengubah } \\
\text { anda untuk lebih menjimatkan tenaga } \\
\text { elektrik? }\end{array}$ & Tidak & $46 \%$ \\
\hline \multirow{2}{*}{$\begin{array}{l}\text { Sikap terhadap } \\
\text { pembelajaran }\end{array}$} & $\begin{array}{l}\text { 6. Pada pendapat anda, sejauh manakah } \\
\text { pembelajaran Tenaga itu penting? }\end{array}$ & Penting & $56 \%$ \\
\hline & $\begin{array}{l}\text { 7. Adakah anda berminat dengan Tajuk } \\
\text { Tenaga dan Elektrik yang dipelajari? }\end{array}$ & Kurang minat & $43 \%$ \\
\hline \multirow{3}{*}{$\begin{array}{l}\text { Pengalaman } \\
\text { Pembelajaran }\end{array}$} & $\begin{array}{l}\text { 8. Adakah tajuk Tenaga susah untuk } \\
\text { dipelajari? }\end{array}$ & Susah & $55 \%$ \\
\hline & $\begin{array}{l}\text { 9. Adakah tajuk Elektrik susah untuk } \\
\text { dipelajari? }\end{array}$ & Susah & $60 \%$ \\
\hline & $\begin{array}{l}\text { 10. Adakah anda seronok dan suka dengan } \\
\text { cara pembelajaran Tajuk Tenaga dan } \\
\text { Elektrik di kelas? }\end{array}$ & Kurang seronok & $50 \%$ \\
\hline \multirow{3}{*}{$\begin{array}{l}\text { Keperluan } \\
\text { strategi } \\
\text { pembelajaran }\end{array}$} & $\begin{array}{l}\text { 11. Pilih satu cara pembelajaran yang anda } \\
\text { sangat suka untuk mempelajari Tajuk } \\
\text { Tenaga dan Elektrik }\end{array}$ & $\begin{array}{c}\text { Pembelajaran } \\
\text { berasaskan projek }\end{array}$ & $55 \%$ \\
\hline & $\begin{array}{l}\text { 12. Adakah anda memerlukan modul dan } \\
\text { panduan untuk mempelajari tajuk tersebut? }\end{array}$ & Ya & $85 \%$ \\
\hline & $\begin{array}{l}\text { 13. Adakah anda berminat untuk } \\
\text { mempelajari tajuk tersebut melalui Projek } \\
\text { Pembelajaran STEM? }\end{array}$ & $\mathrm{Ya}$ & $81.7 \%$ \\
\hline
\end{tabular}




\section{Perbincangan Kajian}

Guru dan murid menyatakan topik Tenaga dan Elektrik sebagai topik yang dianggap sukar untuk belajar dan mengajar. Kedua-dua topik ini adalah berada dalam tema kumpulan sains fizikal. Dapatan ini berpadanan dengan kajian terdahulu yang menunjukkan bahawa konsep sains khususnya yang berada di dalam kumpulan Fizik sering sahaja dianggap sebagai abstrak dan sukar (Duit, 1984; Tsagliotis, 2005; Yuenyong \& Yuenyong, 2007). Berdasarkan kepada dapatan kajian ini, modul yang dibangunkan sebaiknya berfokuskan kepada topik sains tersebut kerana ia mungkin berkemampuan untuk meningkatkan pencapaian murid terhadap subjek yang sukar. Semasa mempelajari subjek sains, murid jarang dilibatkan pendekatan yang melibatkan pengintegrasian pendidikan STEM kerana guru lebih cenderung untuk mengamalkan pengajaran berpusatkan guru. Hal ini menjadi faktor topik Tenaga dan Elektrik sukar diaplikasikan dalam kehidupan serta membosankan (Abdul Aziz 2008). Kajian terdahulu menunjukkan intervensi pengintegrasian pendidikan STEM melalui pendekatan berasaskan projek (Han, Capraro, \& Capraro, 2014; Lee \& Kamisah, 2015; Wan Nor, 2016), mampu untuk meningkatkan minat, pencapaian, kemahiran dan merapatkan jurang pencapaian antara murid. Justeru, intervensi pengintegrasian pendidikan STEM yang dibangunkan perlu mempunyai ciri-ciri PdP yang inovatif melibatkan pengintegrasian pendidikan STEM.

Pembelajaran tajuk Tenaga dan Elektrik didapati masih belum mampu untuk mengubah sikap dan tingkah laku murid untuk lebih menjimatkan tenaga elektrik. Perkara ini mungkin berlaku kerana murid belum melalui pengalaman pembelajaran sains sebenar dalam konteks pengintegrasian pendidikan STEM. Jika murid mempunyai sikap yang positif maka tingkah laku mereka juga akan terdorong ke arah yang positif (Kamisah, Zanaton \& Lilia, 2007). Contohnya, penglibatan diri secara aktif dengan aktiviti pengintegrasian pendidikan STEM seperti menggunakan pengetahuan sains bagi menghasilkan model dan produk melalui amalan kejuruteraan dapat membantu murid untuk menguasai subjek sains dengan lebih mendalam seterusnya mengaplikasikan dalam kehidupan harian (Hayden et al., 2011). Penggunaan peralatan teknologi dan ICT merupakan keperluan yang diinginkan oleh guru dan murid dalam PdP sains. Dalam konteks pengintegrasian pendidikan STEM, teknologi bukan sekadar alat untuk menyokong pembelajaran sains, tetapi ia juga merupakan alat yang dapat menyelesaikan masalah terhadap isu sains yang diutarakan. Penggunaan LCD dan lap top dilihat sudah menjadi kelaziman dan tidak asing bagi guru dan murid di sekolah. Namun penghasilan produk atau proses yang menyelesaikan masalah terhadap isu tersebut juga merupakan satu teknologi. Justeru, penghasilan model seperti kereta dan rumah jimat tenaga daripada modul ini nanti memberi peluang kepada murid dan guru untuk meluaskan lagi definisi mereka tentang teknologi.

\section{Kesimpulan}

Berdasarkan dapatan dan perbincangan dalam kajian analisis keperluan ini maka wujudnya isu dan permasalahan dalam PdP topik Tenaga dan Elektrik dalam kalangan murid Tahun Lima di daerah Kota Kinabalu. Permasalahan ini memerlukan intervensi melalui pembangunan modul literasi tenaga integrasi STEM untuk murid sekolah rendah. Kajian lepas menunjukkan peningkatan pencapaian serta perubahan sikap dan tingkah laku murid berdasarkan pembelajaran menggunakan modul. Dapatan kualitatif akan keperluan sedia ada dan keperluan yang diinginkan serta soal selidik keperluan murid daripada kajian ini menjadi garis panduan dalam mereka bentuk dan membangunkan modul literasi tenaga yang mengintegrasikan pendidikan STEM. Modul ini adalah bermatlamat untuk mencapai peningkatan pencapaian sains dalam topik Tenaga dan Elektrik secara khusus, peningkatan positif sikap murid terhadap tenaga dan tingkah laku terhadap penjimatan tenaga. Akhir sekali, aktiviti pembelajaran serta pengajaran yang terhasil melalui pendekatan yang diusul dalam modul yang dibangunkan nanti dapat diguna sebagai satu sumber panduan PdP kepada guru serta murid secara berkesan di sekolah. 


\section{Rujukan}

Abdul Aziz Abdul Kadir. (2008). Menentukan Komponen-Komponen Pengetahuan Pedagogi Komponen (PPK) Guru Biologi. Tesis Sarjana, Fakulti Pendidikan, Universiti Kebangsaan Malaysia, Bangi.

American Association for the Advancement of Science (AAAS). (1989). Project 2061: Science for all Americans. Washington, DC: Author.

American Association for the Advancement of Science (AAAS). (1993). Benchmarks for Science

American Association for the Advancement of Science (AAAS). (1993). Benchmarks for Science Literacy: Part I: Achieving Science Literacy: Project 2061. Washington, DC: Author.

Asghar, A., Ellington, R., Rice, E., Johnson, F. \& Prime, G.M. (2012). Supporting STEM Education in Secondary Science Contexts. Interdisciplinary Journal of Problem Based Learning 6(2):85-125

Barrow, L. H., \& Morrisey, J. T. (1989). Energy Literacy of Ninth-Grade Students: A Comparison Between Maine and New Brunswick. Journal of Environmental Education, 20(2), 22-25.

Branch, R.M. (2009). Instructional Design: The ADDIE Approach. London: Springer.

Casper, A.N. (2003). analysis. http://linguistics.byu.edu/resources/volunteers/TESOLBYU_NeedsAnalysis. html .15 Sept 2020.

Catherine, C. (2015). Conducting Research Interviews for Business and Managements Students. Sage Publication. London.

Creswell, J.W. (2008). Education Research: Planning, Conducting and Evaluating Quantitative and Qualitative Research. Ed. ke-3. New York: Pearson International Edition.

DeWaters, J.E., \& Powers, S.E. (2008). Improving Energy Literacy Through Project-Based, STS in Fluenced Educational Programs. Poster presented at the 2008 Annual Meeting of the American Association for the Advancement of Science (AAAS): Science and Technology from a Global Perspective, Boston, MA, February 14-18, 2008.

DeWaters, J. E., \& Powers, S. E. (2011). Energy Literacy of Secondary Students in New York State (USA): A Measure of Knowledge, Affect, and Behavior. Energy Policy, 39, 1699-1710.

DeWaters, J. E. \& Powers, S. E. (2013). Establishing Measurement Criteria for An Energy Literacy Questionnaire. Journal of Environmental Education, 44(1), 38-55.

Duit, R. (1984). Learning The Energy Concept in School-Empirical Results from The Philippines and West Germany. Physics Education 19(2):59-66

Han, S., Capraro, R. \& Capraro, M. (2014). How Science, Technology, Engineering, And Mathematics (STEM) Project-Based Learning (PBL) Affects High, Middle, and Low Achievers Differently: The Impact of Student Factors on Achievement. International Journal of Science and Mathematics Education 13(5):1089- 1113.

Harland, D.J. (2011). STEM: Student Research Handbook. Arlington: National Science Teachers Association.

Harun, M. \& Hoque, M. N. (2015). The Role of Solar Home System (SHS) in Socio-Economic Development of Rural Bangladesh. http://dspace.bracu.ac.bd:8080/xmlui/bitstream/handle/10361/5049/Abdullah Harun.pdf?sequence=1 7 JULAI 2020.

Harvey, G. D. (1977). Environmental Education: A Delineation of Substantive Structure. Dissertation Abstracts International 38, 611A-612A.

Hayden, K., Ouyang, Y., Scinski, L., Olszewski, B. \& Bielefeldt, T. (2011). Increasing Student Interest and Attitudes In STEM: Professional Development and Activities To Engage and Inspire Learners. Contemporary Issues in Technology and Teacher Education 11(1):47-69.

Hofman, H. (1980). Energy Crisis-Schools to The Rescue Again. School Science and Mathematics, $80,468-478$.

Hungerford, H. R., Peyton, R. B., \& Wilke, R. (1980). Goals for Curriculum Development in Environmental Education. Journal of Environmental Education, 11(3), 42-47.

James, E. O., Robinson, M., \& Powell, R. R. (1994). Beyond STS: An Energy Education Curriculum Context For The 21st Century. Journal of Science Teacher Education, 5, 6-14.

Jennings, P. \& Lund, C. (2009). New Direction in Renewable Energy Education. Renewable Energy, $34(2), 435-439$. 
Liarakou, G., C. Gavrilakis \& E. Flouri. (2009). Secondary School Teachers' Knowledge and Attitudes Towards Renewable Energy Sources. Journal Science of Education Technology 18:120-129.

Kamisah Osman, Zanaton Hj.Iksan \& Lilia Halim. (2007). Sikap Terhadap Sains Dan Sikap Saintifik DiKalangan Pelajar Sains. Jurnal Pendidikan 32(2007):39-60

Kelley, T.R. \& Knowles, J.G. (2016). A Conceptual Framework for Integrated STEM Education. International Journal of STEM Education 3(11):1-11

Kementerian Pendidikan Malaysia. (2014). Kurikulum Standard Sekolah: Dokumen Standard Kurikulum dan Pentaksiran Sains Tahun Lima. Putrajaya: Bahagian Pembangunan Kurikulum.

Lantz, H.B. (2009). Science, Technology, Engineering, and Mathematics (STEM) Education. What Form? What Function? : http://www.currtechintegrations.com/pdf/STEMEducationArticle.pdf .30 Jun 2020.

Lee Chuo Hiong \& Kamisah Osman. (2015). An Interdisciplinary Approach for Biology, Technology, Engineering and Mathematics (BTEM) to Enhance 21st Century Skills in Malaysia. K-12 STEM Education 1(3):137-147.

McKillip, J. (1987). Need Analysis: Tools for the Human Services and Education. Ed. ke10. California: Sage Publication, Inc.

Moore, T.J., Stolhmann, M.S., Wang, H.-H., Tank, K.M., Glancy, A.W. \& Roehriq, G.H. (2014). Implementation and Integration of Engineering in K-12 STEM Education. Indiana: Purdue University Press.

Morrison, G.R., Ross, S.M., Kemp, J.E. \& Kalman, H.K. (2007). Designing Effective Instruction. Ed. ke-5. Hoboken, New Jersey: John Wiley \& Sons, Inc.

National Science Teachers Association (NSTA). (1971). NSTA Position Statement on School Science Education for The 70s. The Science Teacher, 38, 46-51.

National Research Council (NRC). (1996). National Science Education Standard. Washingtion, DC: National Academic Press.

Ostler, E. (2012). 21st Century STEM Education: A Tactical Model for Long-Range Success. International Journal of Applied 2(1): 28-33.

Patton, M. Q. (2002). Qualitative research and evaluation methods (3rd ed.). Thousand Oaks, CA: Sage

Pearson, G., \& Young, T. (2002). Technically Speaking: Why All Americans Need to Know More About Technology. Washington, D.C: National Academy Press.

Phang, F.A., Mohd Salleh, A., Mohammad Bilal, A. \& Salmiza, S. (2014). Faktor Penyumbang kepada Kemerosotan Penyertaan Pelajar dalam Aliran Sains: Satu Analisis Sorotan Tesis. Sains Humanika 2(4): 63-71

Reeve, E.M. (2015). STEM Thinking! Technology and Engineering Teacher. December/January 2015: 8-16.

Ritchie, J. \& J. Lewis. (2003). Qualitative Research Practice : A Guide for Social Science Students and Researchers. London: Sage.

Salmon, J. (2000). Are We Building Environmental Literacy?. Journal of Environmental Education, 31(4), 4-10.

Smith, P.L. \& Ragan, T.J. (2005). Instructional Design. Ed. ke-3. Hoboken, N.J: J. Wiley \& Sons.

Saedah Siraj, Norlidah Alias, Dorothy Dewitt \& Zaharah Hussin. (2013). Design and Developmental Research. Emergent Trends in Educational Research. Kuala Lumpur: Pearson.

Solomon, J. (1992). Getting To Know About Energy: In School and Society. London, UK: The Ealmer Press

Tenaw, Y.A. (2014). Teacher Attitude, Experience And Background Knowledge Effect On The Use of Inquiry Method of Teaching. International Research Journal of Teacher Education 1(1):2-9.

Tsagliotis, N. (2005). Hands-on Science Activities for The Teaching and Learning of Mechanical Energy with 6th Grade Primary School Children in Greece. Kertas kerja Hands-on Science: Science in a Changing Education. Anjuran University of Crete campus at Rethymno, Greece, 1316 Julai.

Wang, H.H., Moore, T.J., Roehrig, G.H. \& Park, M.S. (2011). STEM Integration: Teacher Perceptions and Practice. Journal of Pre-College Engineering Education Research (J-PEER) 1(2):1-13.

Wiggins, G., \& McTighe, T. (2003). Understanding by design. Exp. $2^{\text {nd }}$ ed. Alexandria, VA: Association for Supervision and Curriculum Development. 
Yuenyong, C. \& Yuenyong, J. (2007). Grade 1 To 6 Thai Students' Existing Ideas About Energy. Science Education International, 18(4):289-298.

Wan Nor Fadzilah Wan Husin, Nurazidawati Mohamad Arsad, Oziah Othman, Lilia Halim, Mohamad Sattar Rasul, Kamisah Osman \& Zanaton Iksan. (2016). Fostering Students' 21st Century Skills Through Project Oriented Problem Based Learning (POPBL) In Integrated STEM Education Program. Asia-Pacific Forum on Science Learning and Teaching 17(1):1-18. 